Article

\title{
Effect by Alkaline Flocculation of Algae and Phosphorous from Water Using a Calcined Waste Oyster Shell
}

\author{
Gnu Nam ${ }^{1} \mathbb{D}^{\mathbb{D}}$, Young-Hoon Choi ${ }^{2}$, Namju Lee ${ }^{1}$ and Ji Whan Ahn ${ }^{1, *}$ \\ 1 Center for Carbon Mineralization, Korea Institute of Geoscience and Mineral Resources, \\ Daejeon 34132, Korea; gnunam@kigam.re.kr (G.N.); nj9468@nate.com (N.J.L.) \\ 2 Department of Advanced Materials Technology, Daesung MDI, Yeongwol 33058, Korea; \\ goodstart21c@naver.com \\ * Correspondence: ahnjw@kigam.re.kr; Tel.: +82-42-861-3990
}

Received: 7 August 2017; Accepted: 30 August 2017; Published: 6 September 2017

\begin{abstract}
Alkaline flocculation has been considered as a potential candidate to remove algae and eutrophic substances from water. A number of researches using low-cost and environmentally friendly methods have been suggested to optimize removal efficiency. In this study, a calcium-containing waste oyster shell, as an environmentally friendly substance, has been used to treat phosphorous, a eutrophic substance, and to remove algae from the fresh water simultaneously. The X-ray Fluorescence (XRF) analysis showed that $\mathrm{CaO}$ was a major phase in a raw oyster shell, which played an important role for flocculation of phosphorous as well as algae. In order to eliminate the algae or phosphorous effectively, oyster shell was calcined at $1000{ }^{\circ} \mathrm{C}$ and hydrated in water. The slurry of hydrated calcined oyster shell, from $5 \mathrm{~g} / \mathrm{L}$ to $12.5 \mathrm{~g} / \mathrm{L}$, was utilized in this experiment, where the experimental results were compared with that of dolomite. A series of experimental investigations, such as $\mathrm{pH}$ and turbidity changes using the water quality analyzer and UV-Visible spectroscopy (UV-Vis), demonstrated that the algae were efficiently removed. In addition, total phosphorous (TP) and total nitrogen (TN) analyses at different amounts of slurries of the hydrated calcined oyster shell showed that almost all the phosphorous was removed at $7.5 \mathrm{~g} / \mathrm{L}$ of hydrated oyster shell, but due to the high solubility of nitrogen compounds, no obvious effect for the removal of nitrogen was observed. Furthermore, powder X-ray diffractions (PXRD) showed that $\mathrm{Ca}(\mathrm{OH})_{2}$ compounds were transformed to the phosphate compound, suggesting that the oyster shell caused flocculation by chemically forming with phosphorous ions.
\end{abstract}

Keywords: algae; eutrophication; analytical chemistry; environmental chemistry; oyster shell

\section{Introduction}

For several decades, algal blooms by the eutrophication in a fresh water have been considered as a steadily generated worldwide issue, threatening aquatic life, human health, water quality, and fishing operation [1-6]. As examples, in China, main rivers and lakes, such as Yangtz River, Songhua River, Wuhan east lake, and Taihu lake, have suffered from extensive algal bloom, raising a problem for drinking water [7]. Additionally, it was reported that the Arctic is melting due to snow algae [8], and researchers in Greenland have been figuring out how algae has sped up the rate at which the ice is melting [9]. In particular, some Asian and developing countries, including Vietnam and South Korea, have been going through severe environmental and social problems due to algal bloom [10-12].

Algae require diverse nutrients including nitrogen, oxygen, phosphorus, silicon, and iron, but populate with feeding mostly phosphorus $(\mathrm{P})$ and nitrogen $(\mathrm{N})$ as major nutrients. $\mathrm{P}$ and $\mathrm{N}$ 
in water mainly arise from the increase of contaminants discharged from sewage and wastewater according to industrialization, leading to a growth of algae by eutrophication.

It has been known that two approaches should be required in order to prevent algae from growth in fresh water. The first is to remove algae using various physical and chemical methods including a waterwheel, chemical reagent, red clay, and ultrasonic waves. The other is to eliminate $\mathrm{N}$ and $\mathrm{P}$ elements causing eutrophication by several methods, such as the chemical coagulation and precipitation [13-21]. Even though various possible methods to treat eutrophication or eliminate algae have been suggested, due to some challenges in cost or efficiency, no best method has been proposed until now.

In recent years, a series of researches using environmentally friendly methods for water treatment, such as the removal of algae or eutrophic substances and heavy metals, have been intensively studied [22-28]. As a few examples, Pan et al. demonstrated that the cationic starch using corn achieves effective removal of algal cells by means of charge neutralization [22]. In addition, chitosan modified soil was utilized as a biodegradable reagent to flocculate the algal cell [23]. Furthermore, Ferhat et al. proved that heavy metals such as copper and zinc were effectively adsorbed by using a modified clay and chitosan [28]. During our previous research for synthesis of precipitated calcium carbonate (PCC) using the oyster shell [29], our group has considered that waste oyster shell can be an environmentally friendly reagent for removing algae or eutrophic substances. It has been reported that hundreds of tons of waste oyster shells are thrown away to temporary storage every year in a few of countries including South Korea and China, which has led to social and environmental issues [30-32]. Since the shell of shellfish possess the Ca element as one of their major components, it can be a potential candidate for the removal of algae or elimination of eutrophic substances by using coagulation and precipitation methods $[33,34]$. In those cases, the $\mathrm{Ca}^{2+}$ ion can flocculate the algae by forming an ionic bond with $\mathrm{CO}_{2}$ or $\mathrm{CO}_{3}{ }^{2-}$ on the surface of the algae or can be crystallized with $\mathrm{PO}_{4}{ }^{3-}$ or $\mathrm{NO}_{3}{ }^{-}$ions to form a few ionic compounds in the solution. In addition to being a novel approach for reducing the environmental pollution itself as well as eliminating algae or eutrophic substances simultaneously, the cheap and renewable oyster shell can be a more powerful candidate than that of the other already suggested reagents. As a preliminary test, our group has first attempted to use oyster shell as an environmentally friendly substance to treat algae [35], but the article was more focused on the synthesis of precipitated calcium carbonate (PCC) by the oyster shell than the analysis for the removal of algae, and detailed experimental and theoretical investigations were not provided.

In this article, we first discuss the experimental and theoretical investigations for the elimination of phosphorous as well as algae by using an oyster shell. The raw oyster shell was further calcined and hydrated to maximize the reactivity in the algal solution. A series of turbidity, UV-Visible spectrum (UV-Vis), total phosphorous (TP), and total nitrogen (TN) analyses at different amount of slurries of the hydrated calcined oyster shell were provided. In addition, the compounds before and after the reaction were characterized by the powder X-ray diffraction (PXRD).

\section{Materials and Methods}

\subsection{Sample Preparation}

Algae-containing water used in this study was collected directly from Geum River located near Okcheon-gun in South Korea. In order to cultivate the algae sufficiently, $11 \mathrm{~g}$ of $\mathrm{K}_{2} \mathrm{HPO}_{4}$ and $5 \mathrm{~g}$ of $\mathrm{NH}_{4} \mathrm{NO}_{3}$ with 1:1 molar ratio were added in $5000 \mathrm{~mL}$ of distilled water to provide eutrophic substances. Then, $500 \mathrm{~mL}$ of the algae-containing water was diluted in the $5000 \mathrm{~mL}$ of prepared solution. The diluted algal solution was cultivated in an illuminating incubator (IL3, JEIO TECH, Daejeon, Korea) with continuous white fluorescent light of about 3000 lux set on $12 \mathrm{~h}$ light and $12 \mathrm{~h}$ darkness for seven days, and the temperature was maintained at $30^{\circ} \mathrm{C}$.

Waste oyster shells were obtained from a temporary waste storage near the seaside of Geojedo in South Korea. Obtained oyster shells were cleaned by the water and ethyl alcohol to eliminate 
impurities on the surface of the shell, which was further dried in an oven, ground to fine powders, and sieved under $100 \mu \mathrm{m}$ before use. The prepared fine powers of oyster shell were calcined by an electric furnace at $1000{ }^{\circ} \mathrm{C}$ for $2 \mathrm{~h}$. The calcined oyster shell was crushed with a mortar and separated under $75 \mu \mathrm{m}$ with a sieving machine. The slurry of a calcined oyster shell was obtained by the hydration process using a wet ball mill method on a high density poly ethylene (HDPE) container including alumina balls sized with the $25 \mathrm{~mm}$ diameter at $108 \mathrm{rpm}$ for $2 \mathrm{~h}$, where the mass ratio between oyster shell and distilled water was $25 \%$ to $75 \%$.

\subsection{Experimental and Structural Analysis}

Removal experiments of algae as well as eutrophic substances such as phosphorous and nitrogen were conducted in the $1000 \mathrm{~mL}$ beaker containing $500 \mathrm{~mL}$ of cultivated algal solution. Different amounts of slurries of hydrated calcined oyster shell from $5 \mathrm{~g}$ to $12.5 \mathrm{~g}$ were added in $500 \mathrm{~mL}$ of algae-containing solution. For comparison, a series of examinations with the same experimental conditions using a Ca-containing dolomite kiln dust, considered as another possible substance for elimination of the algae, was performed. After the slurry was added onto the algal solution, initial color change was observed and further stirred with a glass rod for $5 \mathrm{~s}$ to induce the homogeneous coagulation reaction. After then, the sufficiently precipitated sludge was separated by filtration process and was dried for structural analysis using the powder X-ray diffraction (X'Pert Pro PW3040, PANalytical, Almelo, The Netherlands). For comparison, the structural information of a hydrated oyster shell was obtained by the powder X-ray diffraction (PXRD). Furthermore, $\mathrm{X}$-ray fluorescence (XRF) measurement was conducted to identify the chemical components of the untreated oyster shell. Samples obtained from the reaction were analyzed to determine the $\mathrm{pH}$ and turbidity using a water quality analyzer (DKK-TOA WQC-24, DKK-TOA, Shinjuku, Japan) and to figure out the total phosphorous and nitrogen contents using HS-3300 (Humas, Daejeon, Korea). Furthermore, absorption spectra of obtained samples were measured in the range from $250 \mathrm{~nm}$ to $700 \mathrm{~nm}$ to check the existence of microorganisms in the solution using the UV-Vis spectrometer (SINCO S-3100, Seoul, Korea).

\section{Results and Discussion}

\subsection{Characterization}

During the research, our group has found that since the limestone and dolomite contained much of the Ca species, the experiments using both of them resulted in an outstanding removal efficiency of algae. To identify the chemical components in the oyster shell, a raw oyster shell was characterized by the X-ray Fluorescence (XRF), in which the result was compared with that of limestone and dolomite. As shown in Table 1, the limestone includes a large amount of $\mathrm{CaO}$ and a small amount of $\mathrm{SiO}_{2}$ and $\mathrm{MgO}$ as minor phases. On the other hand, a dolomite showing a chemical composition of $\mathrm{CaMg}\left(\mathrm{CO}_{3}\right)_{2}$ has the $\mathrm{Mg}$ as well as $\mathrm{Ca}$ as major components. In the case of an oyster shell, as similar with a limestone, the Ca was observed as a component with the highest concentration. Since similar chemical components as the limestone were identified in the oyster shell, the reactivity with the algae by an oyster shell will be expected to be similar to the reactivity by a limestone.

Table 1. A result of X-ray Fluorescence (XRF) Analysis for limestone, dolomite and oyster shell.

\begin{tabular}{cccccccccccc}
\hline & $\mathrm{SiO}_{2}$ & $\mathrm{Al}_{\mathbf{2}} \mathbf{O}_{\mathbf{3}}$ & $\mathrm{Fe}_{2} \mathbf{O}_{\mathbf{3}}$ & $\mathbf{C a O}$ & $\mathbf{M g O}$ & $\mathbf{K}_{\mathbf{2}} \mathbf{O}$ & $\mathbf{N a}_{\mathbf{2}} \mathbf{O}$ & $\mathrm{TiO}_{2}$ & $\mathbf{M n O}$ & $\mathbf{P}_{\mathbf{2}} \mathbf{O}_{\mathbf{5}}$ & Igloss \\
\hline Limestone & 0.11 & 0.03 & 0.09 & 55.54 & 0.20 & 0.03 & $<0.02$ & $<0.01$ & 0.01 & 0.01 & 43.79 \\
Dolomite & 0.06 & 0.04 & 0.18 & 31.27 & 21.81 & 0.03 & $<0.02$ & 0.01 & 0.07 & 0.01 & 46.37 \\
Oyster shell & 0.45 & 0.12 & 0.06 & 53.66 & 0.26 & 0.06 & 0.55 & $<0.01$ & 0.01 & 0.16 & 44.56 \\
\hline
\end{tabular}

To investigate the reactivity of the calcined oyster shell in the solution, the hydration activity was measured depending on the time, in which good hydration activity gives rise to better reactivity with particular species in the solution. Hydration activities of quicklime and dolomite kiln dust samples were also measured for comparison with that of a calcined oyster shell. As shown in Figure 1, 
temperature was increased depending on the time in all three samples that showed an exothermic reaction, but all of them revealed different patterns of hydration activity in the solution. The quicklime showed rapid hydration activity in a short time, and the maximum temperature was observed at $70^{\circ} \mathrm{C}$. On the other hand, dolomite kiln dust showed that the temperature quite slowly increased up to $48^{\circ} \mathrm{C}$ in the $600 \mathrm{~s}$. In the case of calcined oyster shell, the hydration activity was so slow that the maximum temperature did not arrive in a given time. Even though both limestone and oyster shell showed the analogous chemical elements by the XRF analysis and included a similar particle size (under $75 \mathrm{um}$ ), different hydration activity was observed, which might be due to the slightly different contents of some elements such as $\mathrm{Si}$ and $\mathrm{Na}$ in both samples. Since the low hydration activity of reactants leads to less reactivity with substances in the solution, sufficiently hydrated calcined oyster shell was used for the experiment in order to enhance reactivity and reduce reaction time with algae or phosphorous.
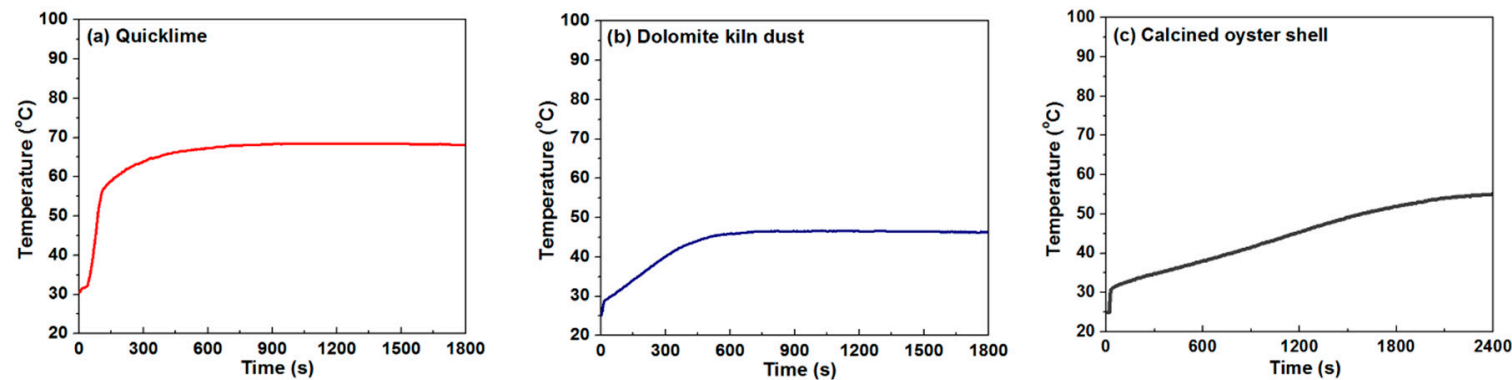

Figure 1. Time dependent curves showing the hydration activity for (a) quicklime; (b) dolomite kiln dust; and (c) calcined oyster shell.

\subsection{Dosage Effect on Chemical Properties}

To investigate the $\mathrm{pH}$ change of the algal solution, different amount of slurries of a calcined oyster shell were added onto the algal solution. In addition, for comparison with a result from a calcined oyster shell, the value of a $\mathrm{pH}$ change of an algal solution with a dolomite kiln dust was also provided. As shown in Figure 2, with the increase of slurry dosage, the $\mathrm{pH}$ of both samples were increased. The $\mathrm{pH}$ of the algal solution with a calcined oyster shell was rapidly increased up to approximately 11.7 at $5.0 \mathrm{~g} / \mathrm{L}$ and relatively stable in the range of $5.0-12.5 \mathrm{~g} / \mathrm{L}$. The reason that the $\mathrm{pH}$ was increased with the raised amount of the slurry can be explained by the following steps. The hydrated $\mathrm{Ca}(\mathrm{OH})_{2}$ from the calcined oyster shell exists as $\mathrm{Ca}^{2+}$ and $\mathrm{OH}^{-}$in the solution. Then, the $\mathrm{Ca}^{2+}$ cations flocculate with some species, such as $\mathrm{CO}_{2}$ or $\mathrm{CO}_{3}{ }^{2-}$, on the surface of the algae or react with phosphorous and nitrogen ions in the solution, in which the concentration of the remaining $\mathrm{OH}^{-}$ions are increased, which brings the $\mathrm{pH}$ to be increased up to approximately 13.0.

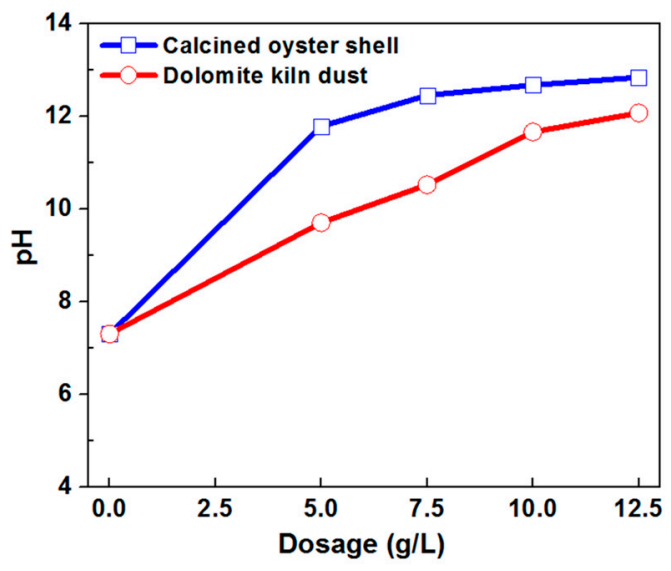

Figure 2. $\mathrm{pH}$ change at a different amount of the calcined oyster shell and dolomite kiln dust. 
Moreover, higher $\mathrm{pH}$ values at the solution of a calcined oyster shell were observed when compared with that of a dolomite kiln dust in the whole added amount of range, which can be explained by following two reasons. First, $\mathrm{Mg}(\mathrm{OH})_{2}$ compounds in the dolomite kiln dust show a quite low solubility $\left(0.0064 \mathrm{~g} / \mathrm{L}\right.$ at $\left.25^{\circ} \mathrm{C}\right)$ rather than the $\mathrm{Ca}(\mathrm{OH})_{2}\left(1.73 \mathrm{~g} / \mathrm{L}\right.$ at $\left.20^{\circ} \mathrm{C}\right)$, which provides the low concentration of $\mathrm{OH}^{-}$ion in the solution. In addition, based on the Le Châtelier's principle, in a reaction of the equilibrium condition, if any change on the concentration of the reactant or product is subjected, the system readjusts itself to offset the effect of the given change. According to this principle, since dolomite kiln dust consists of $\mathrm{Mg}(\mathrm{OH})_{2}$ as well as $\mathrm{Ca}(\mathrm{OH})_{2}, \mathrm{OH}^{-}$ions increased by $\mathrm{Ca}(\mathrm{OH})_{2}$ holding a higher solubility, preventing the $\mathrm{Mg}(\mathrm{OH})_{2}$ from being ionized to $\mathrm{Mg}^{2+}$ and $\mathrm{OH}^{-}$. Those two reasons make the $\mathrm{pH}$ of a solution with dolomite kiln dust less increased. Hence, concentrations of $\mathrm{Ca}^{2+}$ ions provided by the oyster shell can facilitate better coagulation properties than that of dolomite kiln dust.

After putting the calcined oyster shell and dolomite kiln dust as a control group into the cultivated algal solution, subsequent results were shown in Figure 3. When each different amount of slurry was injected on the algal solution, instantaneous color changes were hardly observed with a naked eye on both samples, but a slightly faded color was observed in a solution with the slurry of a calcined oyster shell, which shows that coagulation or precipitation time in an algal solution with an oyster shell is more rapid than that of a dolomite. After stirring for $10 \mathrm{~s}$ with a glass bar, the color of both solutions became quite transparent, and a large amount of the sludge was precipitated with the algae. In the case of a solution with the dolomite kiln dust, a less transparent algal solution was observed compared with that of dolomite kiln dust, which arose from the less reactivity by the insoluble $\mathrm{Mg}(\mathrm{OH})_{2}$ from the dolomite kiln dust.

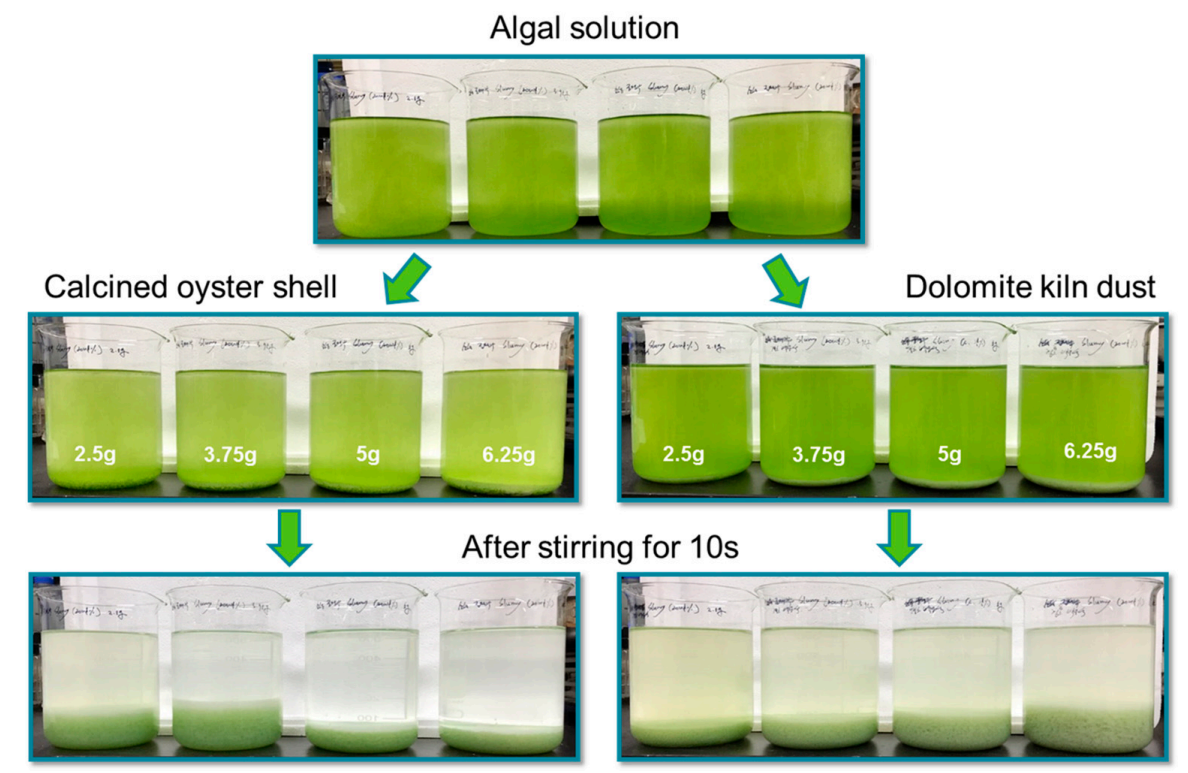

Figure 3. The result showing the changes by using calcined oyster shell and dolomite kiln dust in $500 \mathrm{~mL}$ algae-containing water.

To investigate a more detailed analysis for the transparency of the algal solution, the measurements for turbidity were conducted with a water quality analyzer at different amounts of the slurry. As shown in Figure $4 a$, after the reaction, the turbidity of both solutions diminished proportionally to the amount of the slurry, which verifies the elimination of the algae. From $5 \mathrm{~g} / \mathrm{L}$, the turbidity of the solution with the slurry of a calcined oyster shell dropped to more than that of the dolomite kiln dust. This phenomenon was due to the fact that the relatively less soluble $\mathrm{Mg}(\mathrm{OH})_{2}$ of the hydrated dolomite kiln dust was included in the algal solution, providing low concentration of $\mathrm{Mg}^{2+}$ ions to flocculate the algae, which was in agreement with the result from $\mathrm{pH}$ test. 

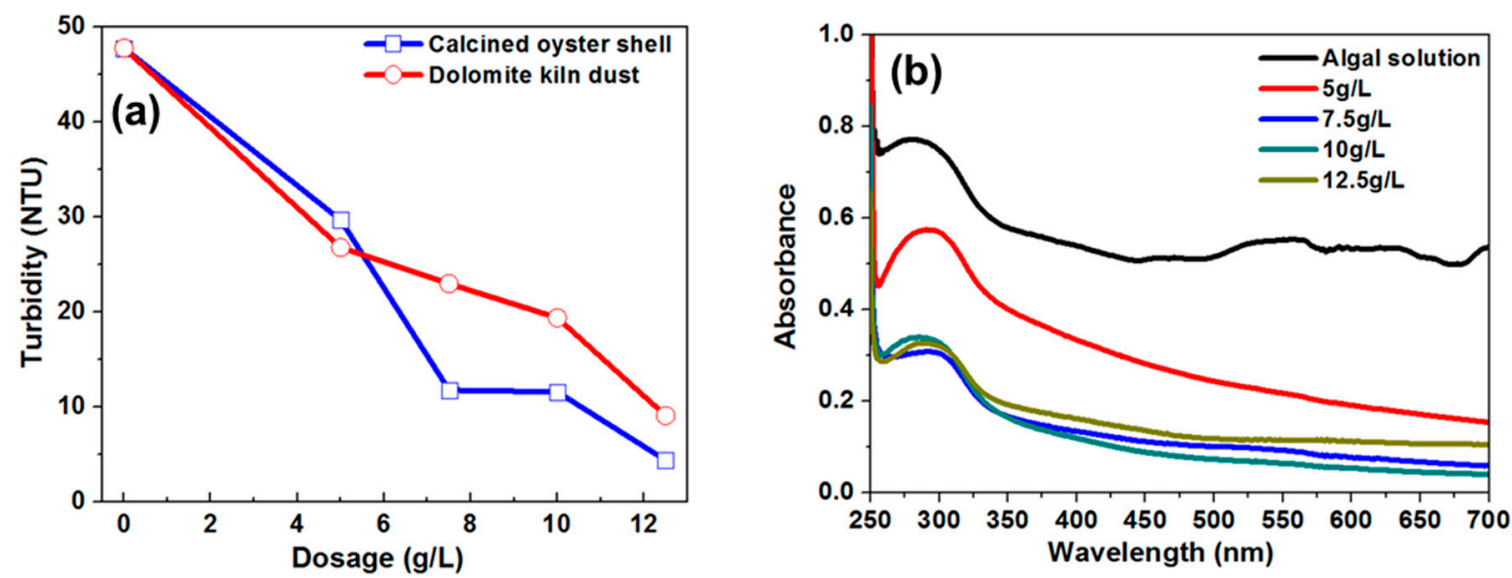

Figure 4. (a) Turbidity of the green algal solution at a different amount of the calcined oyster shell and dolomite kiln dust; and (b) UV-visible absorption spectra from 250 to $700 \mathrm{~nm}$ for the algal solution at different adding contents of calcined oyster shell.

Furthermore, absorption spectra for the algal solution were plotted to investigate the characteristics of microorganisms in the algal solution at different adding contents of the slurry in the range from $250 \mathrm{~nm}$ to $700 \mathrm{~nm}$ using the UV-Vis spectroscopy, shown in Figure $4 \mathrm{~b}$. In the range of the ultra violet region, UV-C represents the region from $250 \mathrm{~nm}$ to $280 \mathrm{~nm}$, and it was known that the microorganism absorbs the light of UV-C [36,37]. Since the alga is a sort of plant-like microorganisms, it can absorb the light of UV-C region. In the case of an untreated algal solution, a large absorption peak was observed at near $280 \mathrm{~nm}$, which was further diminished as the added amount of slurry increased up to $7.5 \mathrm{~g} / \mathrm{L}$, and in the range from $7.5 \mathrm{~g} / \mathrm{L}$ to $12.5 \mathrm{~g} / \mathrm{L}$, a similar absorption intensity was observed. Thus, it was demonstrated that the addition of a slurry of the oyster shell into the algal solution is effective for the elimination of microorganisms forming algae.

For the elimination of algae, cation sources play important roles for the precipitation by the crystallization formed by the ionic bonding with a phosphorous ion contributing an eutrophication as well as for a coagulation by the chemical reaction on the surface of algae. To verify the reactivity for the phosphorous ion with $\mathrm{Ca}^{2+}$ ions from the oyster shell, the concentration of total phosphorous (TP) in the algal solution was measured at a different adding amount of the slurry of a calcined oyster shell and dolomite kiln dust as a comparison. As shown in Figure 5a, as the added amount of the slurries, the concentration of TP was diminished. Particularly, in the case of a calcined oyster shell, TP was rapidly decreased up to an initial $7.5 \mathrm{~g} / \mathrm{L}$ and resulted in the elimination of almost all concentration of phosphorous in the algal solution. On the other hand, dolomite kiln dust did not have an effect on the concentration of the phosphorous until $5.0 \mathrm{~g} / \mathrm{L}$ and after then, the concentration was rapidly dropped. However, unlike the case of an oyster shell, complete removal of phosphorous was not reached with the dolomite sample, which demonstrates that the oyster shell is a better reagent for the elimination of phosphorous ion in the solution than the dolomite. This phenomena is due to the fact that a lack of $\mathrm{Ca}^{2+}$ ions in the dolomite sample provides less sources to bond with phosphorous ions. Therefore, dolomite requires more slurry dosages to treat the phosphorous from water than the oyster shell. The $\mathrm{Ca}^{2+}$ ion in an oyster shell or dolomite can be crystallized with phosphorous ion as a form of $\mathrm{Ca}_{3}\left(\mathrm{PO}_{4}\right)_{2}$ or $\mathrm{Ca}_{5}\left(\mathrm{PO}_{4}\right)_{3} \mathrm{OH}$ by Equations (1) and (2), which can be further confirmed by the structural analysis with powder $\mathrm{X}$-ray diffractions and was discussed on next section.

$$
\begin{gathered}
3 \mathrm{Ca}^{2+}(\mathrm{aq})+2 \mathrm{PO}_{4}{ }^{3-}(\mathrm{aq}) \leftrightarrow \mathrm{Ca}_{3}\left(\mathrm{PO}_{4}\right)_{2}(\mathrm{~s}, \mathrm{aq}) \\
5 \mathrm{Ca}^{2+}(\mathrm{aq})+\mathrm{OH}^{-}(\mathrm{aq})+3 \mathrm{PO}_{4}{ }^{3-}(\mathrm{aq}) \leftrightarrow \mathrm{Ca}_{5}\left(\mathrm{PO}_{4}\right)_{3} \mathrm{OH}(\mathrm{s}, \mathrm{aq})
\end{gathered}
$$



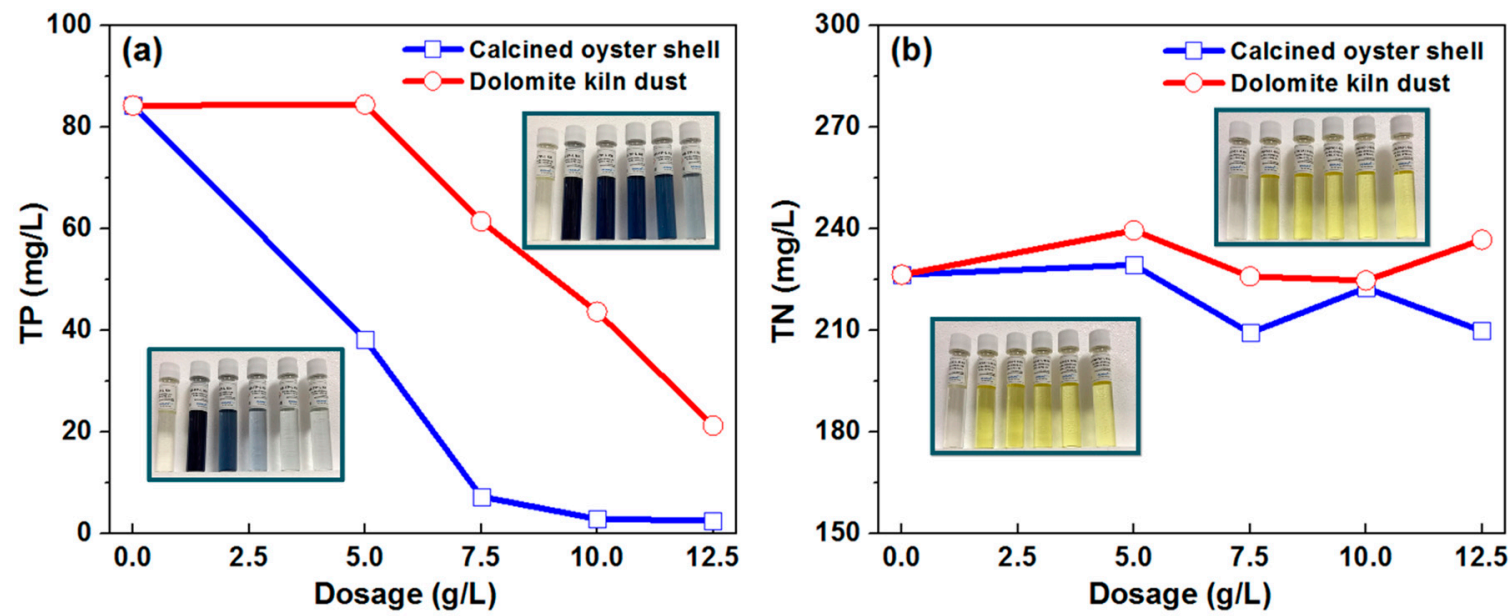

Figure 5. (a) Total phosphorus (TP) and (b) total nitrogen (TN) of the green algal solution at a different amount of the calcined oyster shell and dolomite kiln dust.

In addition to the phosphorous, nitrogen also causes an algal growth. To investigate the elimination of nitrogen in the algal solution, the concentration of the total nitrogen (TN) was measured at the different amounts of the slurry. As shown in Figure 5b, it was found that no obvious effect on the concentration of $\mathrm{TN}$ was observed with both samples. This phenomenon can be explained using two mechanisms. First, nitrogen generally exists as an $\mathrm{NO}_{3}{ }^{-}$ion in the solution and reacts with $\mathrm{Ca}^{2+}$ ion to form $\mathrm{Ca}\left(\mathrm{NO}_{3}\right)_{2}$, shown in below Equation (3). However, $\mathrm{Ca}\left(\mathrm{NO}_{3}\right)_{2}$ possesses good solubility and exists as a form of an ion as $\mathrm{Ca}^{2+}$ and $\mathrm{NO}_{3}{ }^{-}$in the aqueous solution, and thus the concentration of a nitrogen seems to remain without any changes in the solution. Besides, as described by Equation (4), since $\mathrm{Ca}\left(\mathrm{NO}_{3}\right)_{2}$ can react with $\mathrm{PO}_{4}{ }^{3-}$ ion in the solution, which is apt to $\left.\mathrm{PO}_{4}\right)_{2}$ [38], concentration of the $\mathrm{NO}_{3}{ }^{-}$ion still remains without any changes. Second, in addition to the $\mathrm{NO}_{3}{ }^{-}$, nitrogen can exist as an ammonium $\left(\mathrm{NH}_{4}{ }^{+}\right)$ion in the solution. The ammonium ions cannot react with other cations such as $\mathrm{Ca}^{2+}$ and react with the anions such as $\mathrm{OH}^{-}$ion in the water, forming $\mathrm{NH}_{4} \mathrm{OH}$ compound. However, since the $\mathrm{NH}_{4} \mathrm{OH}$ compound is also soluble in the water, the $\mathrm{NH}_{4}{ }^{+}$ion remains as it is in the solution. Although the oyster shell did not treat the nitrogen element in the algal solution, algae cannot be grown up for just removing the phosphorous element [39].

$$
\begin{gathered}
\mathrm{Ca}^{2+}(\mathrm{aq})+2 \mathrm{NO}_{3}{ }^{-}(\mathrm{a}) \rightarrow \mathrm{Ca}\left(\mathrm{NO}_{3}\right)_{2}(\mathrm{aq}) \\
3 \mathrm{Ca}\left(\mathrm{NO}_{3}\right)_{2}(\mathrm{aq})+2 \mathrm{PO}_{4}{ }^{3-}(\mathrm{aq}) \leftrightarrow \mathrm{Ca}_{3}\left(\mathrm{PO}_{4}\right)_{2}(\mathrm{~s}, \mathrm{aq})+6 \mathrm{NO}_{3}{ }^{-}(\mathrm{aq})
\end{gathered}
$$

\subsection{Structural Analysis}

As briefly mentioned above, two $\mathrm{Ca}_{3}\left(\mathrm{PO}_{4}\right)_{2}$ and $\mathrm{Ca}_{5}\left(\mathrm{PO}_{4}\right)_{3} \mathrm{OH}$ compounds can be produced by the reaction with $\mathrm{Ca}^{2+}$ of an oyster shell and $\mathrm{PO}_{4}{ }^{3-}$ in the water, which was confirmed by the powder $\mathrm{X}$-ray diffraction measurements. Figure 6a shows the $\mathrm{X}$-ray diffraction patterns of a hydrated calcined oyster shell powder before the reaction. As expected, $\mathrm{CaO}$ as a major phase of an oyster shell was changed to $\mathrm{Ca}(\mathrm{OH})_{2}$ by the hydration process with $\mathrm{H}_{2} \mathrm{O}$. In addition, due to the carbonation process of $\mathrm{Ca}^{2+}$ ions with $\mathrm{CO}_{3}{ }^{2-}$ ions in the water, the small amount of calcite $\left(\mathrm{CaCO}_{3}\right)$ phase was observed in the $\mathrm{X}$-ray patterns. Figure $6 \mathrm{~b}$ shows the $\mathrm{X}$-ray patterns at a different amount of the slurry after the reaction. Any diffraction peaks for $\mathrm{Ca}(\mathrm{OH})_{2}$ were not detected, but a new large peak at near $32^{\circ}$ was observed, which represents the hydroxylapatite, $\mathrm{Ca}_{5}\left(\mathrm{PO}_{4}\right)_{3} \mathrm{OH}$, adopting the hexagonal $\mathrm{P63} / \mathrm{m}$. In other words, almost all calcium species were consumed for the chemical bonding with phosphate ion $\left(\mathrm{PO}_{4}{ }^{3-}\right)$. In addition to the formation of a hydroxylapatite, calcite $\left(\mathrm{CaCO}_{3}\right)$ can also be obtained by the reaction of $\mathrm{Ca}^{2+}$ with $\mathrm{CO}_{2}$ or $\mathrm{CO}_{3}{ }^{2-}$ onto the surface of the algae [34]. Interestingly, X-ray patterns indicate that the contents of a calcite phase were increased proportionally to the added amount of the 
slurry, which might be due to the fact that the $\mathrm{Ca}^{2+}$ ion reacts with $\mathrm{PO}_{4}{ }^{3-}$ ion prior to the reaction with $\mathrm{CO}_{2}$ or $\mathrm{CO}_{3}{ }^{2-}$. Then, as the amount of the slurry was increased, the remaining $\mathrm{Ca}^{2+}$ ion reacts with $\mathrm{CO}_{2}$ and $\mathrm{CO}_{3}{ }^{2-}$, forming a $\mathrm{CaCO}_{3}$.
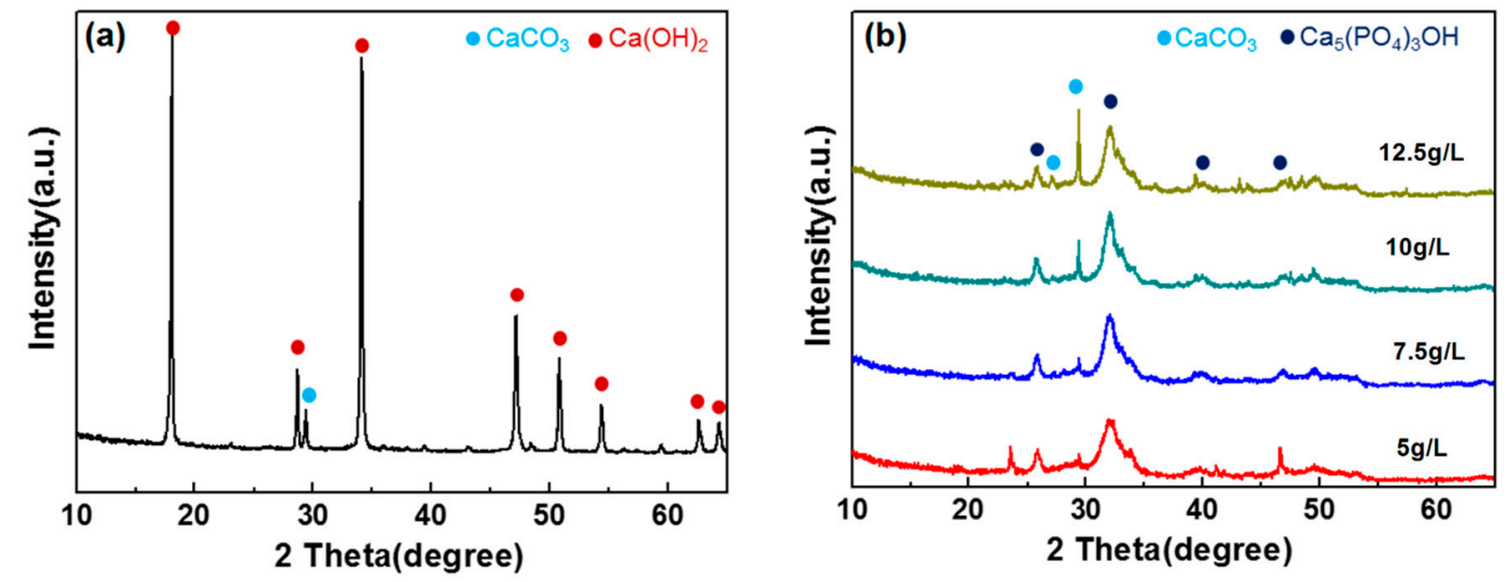

Figure 6. Powder X-ray diffraction patterns of (a) hydrated oyster shell powder and (b) final products at the different amount of calcined oyster shell.

In addition, X-ray diffraction patterns of a dolomite kiln dust were collected, shown in Figure S1 (Supplementary Materials). Different from the calcined oyster shell, hydrated dolomite kiln dust contains $\mathrm{Mg}(\mathrm{OH})_{2}$ as well as $\mathrm{Ca}(\mathrm{OH})_{2}$ as major phases, and after the reaction, as shown in the Figure $\mathrm{S} 1 \mathrm{~b}, \mathrm{Mg}(\mathrm{OH})_{2}$ didn't take part in the reaction and remained in the final sludge, which is due to the fact that the solubility of $\mathrm{Mg}(\mathrm{OH})_{2}\left(0.0064 \mathrm{~g} / \mathrm{L}\right.$ at $\left.25^{\circ} \mathrm{C}\right)$ is relatively lower than that of $\mathrm{Ca}(\mathrm{OH})_{2}$ $\left(1.73 \mathrm{~g} / \mathrm{L}\right.$ at $\left.20^{\circ} \mathrm{C}\right)$, which prevents $\mathrm{Mg}(\mathrm{OH})_{2}$ from participating in the reaction with other species.

Although this cheap and renewable oyster shell can be considered as a potential candidate to treat the algae and eutrophic substances from wastewater, high $\mathrm{pH}$ or precipitated sludge are other challenges. For these practical problems, a solution may be achieved with other methods such as modifying the oyster shell with chemical reagents or adding some substances to remove the sludge.

\section{Conclusions}

A novel approach for the removal of phosphorous as well as algae has been conducted using the oyster shell as a cheap and eco-friendly substance. It was demonstrated by the XRF analysis that $\mathrm{CaO}$ was a major phase of an oyster shell, which plays a crucial role on flocculation of the algae and phosphorous. Hydrated calcined oyster shell was utilized to enhance the chemical reactivity with anion species, such as $\mathrm{CO}_{3}{ }^{2-}$ and $\mathrm{PO}_{4}{ }^{3-}$ in the algal solution. As a result of a turbidity measurement, it was proved that the algae were coagulated and precipitated proportionally to the added amount from $5 \mathrm{~g} / \mathrm{L}$ to $12.5 \mathrm{~g} / \mathrm{L}$ as the form of a sludge, and the removal of microorganisms was observed using the UV-Vis spectrum, implying the oyster shell prevents microorganisms from growing up as the algae. In addition, dispersal of a $7.5 \mathrm{~g} / \mathrm{L}$ of calcined oyster shell into the algal solution removed almost all phosphorous element. On the other hand, nitrogen elements were prone to remain in the algal solution ranging from $5 \mathrm{~g} / \mathrm{L}$ to $12.5 \mathrm{~g} / \mathrm{L}$ of hydrated oyster shell due to the good solubility of compounds formed with nitrogen elements. Structural determination by the PXRD showed that $\mathrm{Ca}_{5}\left(\mathrm{PO}_{4}\right)_{3} \mathrm{OH}$ compound was produced as a result of the reaction between the $\mathrm{Ca}^{2+}$ ion from the oyster shell and the $\mathrm{PO}_{4}{ }^{3-}$ ion in the algal solution, then continuing to form $\mathrm{CaCO}_{3}$ as a form by a reaction with $\mathrm{CO}_{2}$ or $\mathrm{CO}_{3}{ }^{2-}$ onto the surface of the algae. As the consequence, this approach achieved an effective removal of algae and phosphorous with quite a small amount of calcined oyster shells in a relatively short time. With some additional studies such as lowering the relatively high $\mathrm{pH}$ accompanied by the reaction and handling the precipitated sludge, the use of renewable oyster shell can reduce cost and environmental concerns to treat the algal blooms. 
Supplementary Materials: The following are available online at www.mdpi.com/2073-4441/9/9/661/s1, Figure S1: Powder X-ray diffraction patterns of (a) dolomite kiln dust powder and (b) final products at the different amount of dolomite kiln dust.

Acknowledgments: This work was supported by the Korea Institute of Energy Technology Evaluation and Planning (KETEP) through the ETI program, Ministry of Trade, Industry and Energy (MOTIE) of the Republic of Korea (Project No. 2013T100100021).

Author Contributions: Ji Whan Ahn conceived of and designed the experiments. Gnu Nam, Young-Hoon Choi and Nam Ju Lee performed the all experimental procedures and measurements. Gnu Nam wrote the paper.

Conflicts of Interest: The authors declare no conflict of interest. The founding sponsors had no role in the design of the study; in the collection, analyses, or interpretation of data; in the writing of the manuscript; nor in the decision to publish the results.

\section{References}

1. Anderson, D.M.; Glibert, P.M.; Burkholder, J.M. Harmful algal blooms and eutrophication nutrient sources, composition, and consequences. Estuaries 2002, 2, 704-726. [CrossRef]

2. Van Dolah, F.M. Marine algal toxins: Origins, health effects, and their increased occurrence. Environ. Health Perspect. 2000, 108, 133-141. [CrossRef] [PubMed]

3. Pearl, H.W.; Gardner, W.S.; McCarthy, M.J.; Peierls, B.L.; Wilhelm, S.W. Algal blooms: Noteworthy nitrogen. Science 2014, 346, 175. [CrossRef] [PubMed]

4. Falconer, I.R. An overview of problems caused by toxic blue-green algae (cyanobacteria) in drinking and recreational water. Environ. Toxicol. 1998, 14, 5-12. [CrossRef]

5. Guo, L. Doing battle with the green monster of Taihu Lake. Science 2007, 317, 1166. [CrossRef] [PubMed]

6. Wolf, D.; Georgic, W.; Klaiber, H.A. Reeling in the damages: Harmful algal blooms' impact on Lake Erie's recreational fishing industry. J. Environ. Manag. 2017, 199, 148-157. [CrossRef] [PubMed]

7. Fu, J. Issue of Cyanobacteria Blooms in Taihu Lake, China. J. Environ. Sci. Manag. 2016, 19, 99-109.

8. Stefanie, L.; Alexandre, M.A.; Rob, R.; Arwyn, E.; Rob, J.N.; Fiona, G.; Liane, G.B. The biogeography of red snow microbiomes and their role in melting arctic glaciers. Nat. Commun. 2016, 7, 11968.

9. Alexandra, W. Algae speed up Greenland ice melt. Nature 2016, 535, 336.

10. Abton, A.; Teoh, P.L.; Mohd-Shaleh, S.R.; Mohammad-Noor, N. First occurrence of Cochlodinium blooms in Sabah, Malaysia. Harmful Algae 2008, 7, 331-336.

11. Chen, C.Y.; Pickhardt, P.C.; Xu, M.Q.; Folt, C.L. Mercury and arsenic bioaccumulation and eutrophication in Baiyangdian Lake, China. Water Air Soil Pollut. 2008, 190, 115-127. [CrossRef] [PubMed]

12. Park, M.G.; Kim, S.; Shim, E.Y.; Yih, W.; Coats, D.W. Parasitism of harmful dinoflagellates in Korean coastal waters. Harmful Algae 2013, 30, S62-S74. [CrossRef]

13. Chekli, L.; Eripret, C.; Park, S.H.; Tabatabai, S.A.A.; Vronska, O.; Tamburic, B.; Kim, J.H.; Shon, H.K. Coagulation performance and floc characteristics of polytitanium tetrachloride (PTC) compared with titanium tetrachloride $\left(\mathrm{TiCl}_{4}\right)$ and ferric chloride $\left(\mathrm{FeCl}_{3}\right)$ in algal turbid water. Sep. Purif. Technol. 2017, 175, 99-106. [CrossRef]

14. Pierce, R.H.; Henry, M.S.; Highan, C.J.; Blum, P.; Sengco, M.R.; Anderson, D.M. Removal of harmful algal cells (Karenia brevis) and toxins from seawater culture by clay flocculation. Harmful Algae 2004, 3, 141-148. [CrossRef]

15. Kwak, D.H.; Kim, S.J.; Jung, H.J.; Won, C.H.; Kwon, S.B.; Ahn, H.W.; Lee, J.W. Removal of clay and blue-green algae particles through zeta potential and particle size distribution in the dissolved air flotation process. Water Sci. Technol. Water Supply 2006, 6, 95-103.

16. Shi, H.X.; Qu, J.H.; Liu, H.J.; Mu, Y.L.; Xiao, K.T.; Wang, L. Effect of ultrasonic irradiation on the coagulation and inactivation of Microcystis. J. Water Supply Res. Technol.-Aqua 2008, 57, 101-108. [CrossRef] 
17. Auvray, F.; van Hullebusch, E.D.; Deluchat, V.; Baudu, M. Laboratory investigation of the phosphorus removal (SRP and TP) from eutrophic lake water treated with aluminium. Water Res. 2006, 40, 2713-2716. [CrossRef] [PubMed]

18. Park, T.; Ampunan, V.; Lee, S.; Chung, E. Chemical behavior of different species of phosphorus in coagulation. Chemosphere 2016, 144, 2264-2269. [CrossRef] [PubMed]

19. Wedi, D.; Konig, E. Elimination of nitrogen and phosphorous from sludge liquor. Water Sci. Technol. 1993, 28, 283-287.

20. Montalve, S.J.; Guerrero, L.E.; Milan, Z.; Borja, R. Nitrogen and phosphorus removal using a novel integrated system of natural zeolite and lime. J. Environ. Sci. Health Part A-Toxic/Hazard. Subst. Environ. Eng. 2011, 46, 1385-1391. [CrossRef] [PubMed]

21. Chen, S.; Xu, J.; Liu, J.; Wei, Q.; Li, G.; Huang, X. Algae separation from urban landscape water using a high density microbubble layer enhanced by micro-flocculation. Water Sci. Technol. 2014, 70, 811-818. [CrossRef] [PubMed]

22. Shi, W.; Tan, W.; Wang, L.; Pan, G. Removal of Microcystis aeruginosa using cationic starch modified soils. Water Res. 2016, 97, 19-25. [CrossRef] [PubMed]

23. Li, L.; Zhang, H.; Pan, G. Influence of zeta potential on the flocculation of cyanobacteria cells using chitosan modified soil. J. Environ. Sci. 2015, 28, 47-53. [CrossRef] [PubMed]

24. Sehaqui, C.; Mautner, A.; de Larraya, U.P.; Pfenninger, N.; Tingaut, P.; Zimmermann, T. Cationic cellulose nanofibers from waste pulp residues and theirnitrate, fluoride, sulphate and phosphate adsorption properties. Carbohydr. Polym. 2016, 135, 334-340. [CrossRef] [PubMed]

25. Li, L.; Pan, G.A. Universal method for flocculating harmful algal blooms in marine and fresh waters using modified sand. Environ. Sci. Technol. 2013, 47, 4555-4562. [CrossRef] [PubMed]

26. Hao, L.; Desai, M.K.; Wang, P.; Valiyaveettil, S. Successive extraction of As(V), Cu(II), and P(V) ions from water using surface modified ghee residue protein. ACS Sustain. Chem. Eng. 2017, 5, 3742-3750.

27. Boonamnuayvitaya, V.; Chaiya, C.Y.; Tanthapanichakoon, W.; Jarudilokkul, S. Removal of heavy metals by adsorbent prepared from pyrolyzed coffee residues and clay. Sep. Purif. Technol. 2004, 35, 11-22. [CrossRef]

28. Ferhat, M.; Kadouche, S.; Drouiche, N.; Messaoudi, K.; Messaoudi, B.; Lounici, H. Competitive adsorption of toxic metals on bentonite and use of chitosan as flocculent coagulant to speed up the settling of generated clay suspensions. Chemosphere 2016, 165, 87-93. [CrossRef] [PubMed]

29. Ramakrishna, C.; Thenepalli, T.; Han, C.; Ahn, J.W. Synthesis of aragonite-precipitated calcium carbonate from oyster shell waste via a carbonation process and its applications. Korean J. Chem. Eng. 2017, 34, 225-230. [CrossRef]

30. Yoon, G.L.; Kim, B.T.; Kim, B.O.; Han, S.H. Chemical-mechanical characteristics of crushed oyster-shell. Waste Manag. 2003, 23, 825-834. [CrossRef]

31. Qin, K.; Wang, T.H.; Huang, J.C.; Huang, C.H.; Hsieh, Y.K.; Wang, C.F.; Tan, C.S. Effect of distribution patterns of refractory overlayers on cyclic high temperature $\mathrm{CO}_{2}$ capture using waste oyster shell. RSC Adv. 2016, 6, 97739-97748. [CrossRef]

32. Moon, D.H.; Cheong, K.H.; Koutsosphros, A.; Chang, Y.Y.; Hyun, S.; Ok, Y.S.; Park, J.H. Assessment of waste oyster shells and coal mine drainage sludge for the stabilization of $\mathrm{As}-, \mathrm{Pb}-$, and $\mathrm{Cu}$-contaminated soil. Environ. Sci. Pollut. Res. 2016, 23, 2362-2370. [CrossRef] [PubMed]

33. Dai, L.; Tan, F.; Li, H.; Zhu, N.; He, M.; Zhu, Q.; Hu, G.; Wang, L.; Zhao, J. Calcium-rich biochar from the pyrolysis of crab shell for phosphorus removal. J. Environ. Manag. 2017, 198, 70-74. [CrossRef] [PubMed]

34. Choi, J.Y.; Kinney, K.A.; Katz, L.E. Effect of $\mathrm{CaCO}_{3(\mathrm{~S})}$ nucleation modes on algae removal from alkaline water. Environ. Sci. Technol. 2016, in press. [CrossRef] [PubMed]

35. Huh, J.H.; Choi, Y.H.; Ramakrishna, C.; Cheong, S.H.; Ahn, J.W. Use of calcined oyster shell powders as $\mathrm{CO}_{2}$ adsorbents in algae-containing water. J. Korean Ceram. Soc. 2016, 53, 429-434. [CrossRef]

36. Monyethabeng, M.M.; Krügel, M. The effect of UV-C treatment on various spoilage microorganisms inoculated into Rooibos iced tea. LWT-Food Sci. Technol. 2016, 73, 419-424. [CrossRef]

37. Gao, Y.; Cui, Y.; Xiong, W.; Li, X.; Wu, Q. Effect of UV-C on algal evolution and differences in growth rate, pigmentation and photosynthesis between prokaryotic and eukaryotic algae. Photochem. Photobiol. 2009, 85, 774-782. [CrossRef] [PubMed] 
38. Safronova, T.V.; Knot'ko, A.V.; Shatalova, T.B.; Evdokimov, P.V.; Putlyaev, V.I.; Kostin, M.S. Calcium phosphate ceramic based on powder synthesized from a mixed-anionic solution. Biomaterials 2016, 73, 25-31. [CrossRef]

39. Vijay, S.; Yuan, Q. Simplified empirical model for phosphorous removal in a facultative wastewater lagoon. J. Environ. Manag. 2017, 201, 1-5. [CrossRef] [PubMed] 